\title{
Developing Enterpreneurship Activity Based on Local Culture in Early Childhood
}

\author{
Diana, Rina Windiarti, Henny Puji Astuti \\ Semarang State University, Semarang, Indonesia \\ e-mail: diana@mail.unnes.ac.id
}

\begin{abstract}
The research is aimed to know the effect of development activities in entrepreneurship based on local culture for early childhood in kindergarten institution. The growing entrepreneurship having a big chance, this is an important part of the in the face of economic growth. On the model of the development of entrepreneurship this learning has been part of the program type of activities hidden curriculum based local culture [1]. There is still limited previous studies on this issue especially in young children, research of Darwanto [2] and Ahmad [3] the introduction of entrepreneurship do at university students. Entrepreneurship in Early Childhood Education refers to foster entrepreneurial spirit which refers to some entrepreneurship values such as honesty, discipline, hard work, creative, innovative, independent, responsible leadership, tenacious, courageous, risk-taking, commitment, realistic, curiosity, communicative and appreciative of achievement [4]. The activities as the treatment was designed based on local culture for developing entrepreneurship. Participants' consent and permission from the school to carry out the study was obtained. the result shows that there was an influence on the value of the children's entrepreneurship. Entrepreneurship program in early childhood is more directed to life skill, but does not close the possibility of a teacher as a child facilitator to provide insight into the economic system. Based on this study, it can be suggested that entrepreneurship program not only develops child life skill but also bring possibility for teacher to support school program.
\end{abstract}

Keywords: Entrepreneurship Activit; Local Culture; Early Childhood.

\section{INTRODUCTION}

As one of the countries with a sizeable population, Indonesia is an advanced country. The total population of Indonesia in 2016 census conducted in 2010 is as many as 237.641.326 inhabitants [5]. The opportunity for entrepreneurship growth is very very big; it also plays an important role in facing the economic ups and downs in the era of Asean Economic Society. The data shows that early childhood institutions also have the chance to be part of this.. The numbers of Early Childhood Institution in Indonesia based on the data in 2015 is about $63 \%$ [6]. This provides a sign that Early Childhood Institutions have the chance to implement entrepreneurship programs to promote local culture in Indonesia. Entrepreneurship education can be done early on by giving an introduction about enterpreneurship to the children, not asking them to be practitioners. Entrepreneurship education for children is the process of shaping their mental to be entrepreneurs, because entrepreneurship does not only teach children about how to do business but also training them to have a firm mental and character [7].

Children can be taught early to recognize themselves, control emotions and stress, manage time, be communicative and flexible in various situations, and can make decisions. The role of teachers in instilling entrepreneurial spirit is very important. The application of the theory illustrated trough an in-class entrepreneurship simulation referred to as " The Challenge"[8]. Teachers can manage entrepreneurial learning activities associated with the preservation or protection of products produced by children.

In some early childhood institutions in Semarang, it was not programmed to have entrepreneurial activities for children. The introduction of entrepreneurship was still very simple and not everything was well planned by the teachers. The design of entrepreneurial learning has not become a necessity for one institution. PAUD institutions have a modified/ developed curriculum that can implement entrepreneurship learning activities in early childhood. 
Based on the background of problems that have been described above, the formulation of the problem in this study are: Do activities based local culture can develop entrepreneurship in early childhood?

According to Steinhoff and John F. Burgess [9] entrepreneur is the person who organizes, manages and dare to risk creating new business and business opportunity. Essentially understanding entrepreneurship is a mental attitude, views, insights and patterns of thinking and patterns of action to the tasks that are responsible and always oriented to the customer. Or it can also be interpreted as all actions of someone who is able to give value and responsibility to the task. A simple definition of entrepreneur is "a person who starts a business and is willing to risk loss in order to make money. It is very important to remember that the common keywords are business and risk. An entrepreneur is recognized to have a real business and able to take risk. Risk-taking is known as the synonym for entrepreneurship. To start and support a business, an entrepreneur has to put his/her career, personal finances and even mental health at stake [10].(Kim, 2008)

The entrepreneurship is a mental attitude and the nature of the soul that is always active in trying to advance the work of dedication in order to increase revenue in business activities. In addition, entrepreneurship is a creative and innovative ability that is used as the basis, tips, and resources to find opportunities for success. The essence of entrepreneurship is the ability to create new and different things through creative thinking and innovative action to create opportunities in facing life's challenges. In essence, entrepreneurship is the nature, characteristics, and character of someone who has the will to realize innovative ideas into the real world creatively.

There are six principles of entrepreneurship [11]: 1) Entrepreneurship is a value shown through attitude, 2) Entrepreneurship is an ability to create something new and different, 3) Entrepreneurship is a process of applying creativity and innovation, 4) Entrepreneurship is a value Which is necessary to start a business, 5) Entrepreneurship is a process of doing something new (creative), and something different (innovative) which is useful to give more value, and 6) Entrepreneurship is an effort to create added value by combining the sources through new and different ways to win the competition.

An early childhood child is a child who is experiencing rapid growth and development. No less important if the child is implanted about life skills.
In Early Childhood institutions it is not difficult to apply the curriculum, because the curriculum of each institution may differ depending on the institution's keynote. The curriculum is a plan for learning in a form of lesson plan. Curriculum development for early childhood education is more emphasized on the aspect of habituation so that what is taught while in the early childhood institutions are remembered and especially will become a habit when the children continue to further education.

Meredith [12] said that characterizes a person with entrepreneurial spirit as a person who (1) is confident, (2) task-oriented and resultant, (3) dares to take risks, (4) has leadership spirits, (5) forwardoriented, and (6) keorisinal.

Life Skills Education is broader than just a working skill, let alone a manual skill. Life Skills education is an educational concept that aims to prepare citizens to learn to have the courage and willingness to face life and life problems naturally without feeling pressured then creatively find solutions and be able to overcome them. The indicators contained in the life skills are conceptually grouped [13]: (1) Self-Knowledge (self awareness) or often also called personal skills, (2) Rational thinking skills or academic skills, (3) Social skills, (4) Vocational skills, which means skills associated with a specific job field and specific skills or technical skills.

Entrepreneurship in Early Childhood Education can be done using a variety of learning media that are expected to concretize the understanding of entrepreneurship in children to foster entrepreneurial spirit which refers to some entrepreneurship values such as honesty, discipline, hard work, creative, innovative, independent, responsible leadership, tenacious, courageous, risktaking, commitment, realistic, curiosity, communicative and appreciative of achievement [4].

Entrepreneurship program in early childhood is more directed to life skill, but does not close the possibility of a teacher as a child facilitator to provide insight into the economic system. The economic system that is commonly done in everyday life is the activity of production, distribution, and consumption. [14]

Conservation is protection. Literally conservation comes from the English language "Conservation" which means protection [15].

Cultural conservation is likened to semprong; a tool made of bamboo that has holes at both ends. Ordinary mothers blow the wind through the semprong to burn the coals. The goal is to keep the fireplace flame steady while cooking. In conclusion, 
blowing fire is not to turn off, but it gives the flow of oxygen to keep its flame [15]. Like conservation, cultural conservation works in much the same way. Local cultural conservation works by keeping creative achievements and processes within cultures together. Local cultural conservation has dimensions backward and forward. The backward dimension is represented by the process of protecting and preserving the local wisdom possessed by the community. Meanwhile, the future dimension is translated by maintaining cultural sustainability.

According to the Directorate General for Formal and Non Formal Education Indonesia policy, their first mission is to develop early childhood education equitably, based on local potential and quality. To meet the mission, Indonesia has the potential of local cultural diversity. [16]

The local cultural conservation raised in this study is the preservation associated with traditional matters. It also looks at activities that can be done by early childhood students. The undertaken local culture concepts were related to entrepreneurship in early childhood, including; designing and developing traditional foods as a form of activity material, creating works that promote local culture such as batik and grazing.

Entrepreneurship that will be made in the model of learning in this research is conservation local culture-based, where children can produce products that have the selling power to lift the local culture where the child lives. The products that are made will be marketed in the child's institution by creating a program of activities called "Market Day" and exhibition of these children's work that will be marketed as gifts/ souvenirs.

\section{METHODS}

This research is included in development research, which aims to develop local culture-based entrepreneurship learning model in kindergarten institutions. In this regard, the method used in was research and development with quantitative descriptive approach, which describes the percentage of the model development results with learning approach that has been designed together for optimal learning. Based on analysis approach, the research is the kind of research quantitative that is the kind of research that emphasizes the analysis on the data is numerical and uses the statistika method.[17]

The location of this research is in Semarang City.This research was conducted in the first semester of 2016/2017 academic year.
The population in this study is all institutions of Kindergarten in Semarang City. The sample is determined by purposive random sampling, which is conducted by choosing the institution in accordance with the criteria that have been determined by the researcher. The samples used in this study were 5 kindergarten institutions representing 5 areas in the city of Semarang. For phase I this research used one of the institutions as a blue print test development model.

To provide meaning to the data that has been collected, in accordance with research questions, and then does the analysis and interpretation. The analysis was done through an evaluation in the form of data percentage to the situation of the issues discussed, including in the review of various aspects and point of view that will be reported in the research.

While interpretation is to interpret, review, identify, and recognize the object of research, then assess the significance of the research object so that it becomes meaningful. The collected data was classified into two groups of data, namely: qualitative data and quantitative data.

\section{RESULT AND DISCUSSION}

This research is completed in the trial product phase in the form of entrepreneurship activities blueprint in early childhood institutions. This trial is still done limited to one of the institutions representing the region in Semarang City. The results of this limited trial are outlined as follows:

The research with title which have been obtained based on the result of data analysis including description of research data, testing requirement analysis, hypothesis testing from result of limited trial in kindergarten, Ngaliyan Semarang City. This study used a trial class (experimental conservation-based entrepreneurial activities), and looks at the children development in entrepreneurial values that are already internalized in the experimental activities. The results of this limited trial have the purpose to see the results of quantitative research conducted through various conservation-based entrepreneurial activities as a form of experimental activity. This is done to see the results of improvements to entrepreneurial values that have been designed through various activities undertaken by the children. In addition, this study also provides qualitative explanations to describe the activities undertaken by children during the research 
The cultivation of entrepreneurship values in this study was built through activities of great interest to young children and incorporated conservation values to preserve the activities and culture of Semarang City in particular. During the research the children's enthusiasm in activities is quite high; it is also a new activity for children with media used by children. Like painting umbrella creations, this activity has never been done, so teachers and children were also very enthusiastic during the research process. Likewise, the activity of grassing with marbles was a process that was quite interesting for children.

Local Culture-based entrepreneurial research provides an invaluable experience for children to export color concepts and teach children to make decisions. This is similar to Masitoh [20] which states that in early childhood learning, the determination of materials to be taught must be in accordance with the objectives to be achieved. The subject matter is usually related to understanding or concept, principle, fact or problem solving. Materials or learning materials should be developed based on experiences or things that children already know, valuable, and fun to learn.

The cultivation of local culture-based entrepreneurship value is basically not only built in PAUD institutions, especially in kindergarten. The family as the first and foremost institution for children to learn everything has a very important role in instilling entrepreneurship value in children. Akbar [21] conveyed about some things that must be considered by parents in supporting the cultivation of entrepreneurship value, including as follows:

a. Appreciate the achievements of children, parents are expected to not give a painful comment or minimize the children's self esteem.

b. Encourage the child at every opportunity to achieve the best prestige.

c. Provide opportunities for children to get along with others.

d. Provide motivation to the children to always be diligent in learning and doing tasks.

The cultivation of conservation-based entrepreneurship values requires participation from various parties, especially from parents and teachers. Award (reward) that can provide spirit, motivation and opportunity for children to be able to work and be creative without having to limit them. In school, the support of teachers gives children the opportunity to be creative in making children's work with the media provided by the teachers. Activities that produce this work are expected to provide economic opportunities for children by marketing their works. Through peak activities in the form of "Market Day" the work of children can be exhibited and marketed. Teachers, parents and community collaboration in providing support for children's activities at school in "Market Day" is very helpful for children to foster children's confidence and appreciate children's work. Children are given the freedom to market their work and determine their own selling price by discussing it first with their peers [1].

\section{CONCLUSIONS}

Based on the results and discussions described above, it can be concluded that in the limited testing phase of one of the institutions related to the model of conservation-based entrepreneurship development in early childhood, it is tcount $<$ ttable $(-38.456$ $<0,000)$. This means that with the development of entrepreneurship based conservation model gives a significant influence to the value of entrepreneurship spirit in early childhood.

The development of entrepreneurship model provides a model of entrepreneurial activity that can be applied in early childhood institutions to foster entrepreneurship spirit in conservation-based early childhood, where children's activities are directed to preserve Indonesian culture such as batik, free drawing in paper paying, market day by selling foods and beverages made by children and other activities that support entrepreneurial spirit in early childhood.

\section{RECOMMENDATION}

Institutions are expected to enter values conservation with local culture-based entrepreneurship program as a program of routine activities for children, so that the value and spirit of entrepreneurship in children can be built early on.

Educators and teachers are suggested to develop values conservation with local culture-based entrepreneurial activities by introducing local activities and cultures from areas of the nearest province to children.

\section{REFERENCES}

[1] Diana. (2016). Development of Conservation Based Entrepreneurship Learning Model for 
Early Childhood In Semarang City. Semarang: UNNES.

[2] Darwanto. (2012). The Role Of Entrepreneurship In Promoting Economic Growth and Increasing People's Welfare. Dissemination of Research on Management \& Business at National Level: State Polytechnic of Semarang.

[3] Ahmad, T., Trihastuti, D., \& Runtuk, J. K. (2013). Analysis of the Effect of Entrepreneurship Education on Student Entrepreneur Behavior.

[4] Curriculum Center for Research and Development of Ministry of National Education. (2010). Development of Entrepreneurship Education; Training Materials for Strengthening Learning Methodology Based on Cultural Values to Form National Competitiveness and Character. Jakarta.

[5] Hadi, http://www.seocontoh.com/2016/01/datajumlah-sensus-penduduk-update-2016.html.

[6] Data Center and Education Statistics. (2014). Ministry of Education and Culture-Indonesia.

[7] Suprodjo, Pusposutardjo. (1999). "Development of Entrepreneurship Culture Through Skills Courses. Paper. Presented in the IUDI Entrepreneurship Insight Seminar, Yogyakarta on 17 and 19 July 1999.

[8] Robinson, P., \& Josien, L. (2014). ENTREPRENEURIAL EDUCATION: USING" THE CHALLENGE" IN THEORY AND PRACTICE. Journal of Entrepreneurship Education, 17(2), 172.

[9] Steinhoff., John, F. Burger. (1989). Small Business Management Fundamentals. Published by Mcgraw-Hill College. ISBN-13: 9780070611504.

[10] Kim, E. (2008). Developing Models to Integrate Early Childhood Education and Childcare in Korea Ock Rhee, 2(1), 53-66.

[11] Suryana. 2013. Entrepreneurship: Tips and processes to succeed. Jakarta: Salemba four.

[12] Geoffrey, G. Meredith., Robert, E. Nelson. The Practice of Entrepreneurship. Publisher: Internasional Labour Office. ISBN-13: 9789221028390.

[13] Academics Entrepreneurs Education for Early Childhood Education Basic and Intermediate.

[14] Rahman, Armaini. 2015. Thesis: Learning to Cultivate Entrepreneurship In Early Childhood.

[15] https://id.wikipedia.org/wiki/konservasi.
[16] Hasan, A. B. P. (2012). Policies and Practices for Promoting Multicultural Awareness of Indigenous Early Childhood Education in Indonesia, 6(1), 63-94.

[17] Azwar, Saifuddin. (2011). Metode Penelitian. Yogyakarta: Pustaka Pelajar.

[18] Wijatno, Serian. (2009). Introduction to Entrepreneurship. Jakarta: Grasindo.

[19] Arianto, Yusuf CK. (2011). The Secrets to Getting Capital \& Facilities Quickly \& Appropriately. Jakarta: Gramedia.

[20] Masitoh, et al. (2009). Kindergarten Learning Strategy. Jakarta: Universitas Terbuka.

[21] Akbar, Reni and Hawadi. (2001). Child Development Psychology. Jakarta: Grasindo. 